\title{
Redactioneel
}

\section{Toezicht als evenwichtskunst}

\author{
Caelesta Braun*
}

Onafhankelijk toezicht betekent vaak laveren tussen meerdere belangen. Het zorgvuldig navigeren tussen te veel of te weinig (inter)nationale politieke bemoeienis, te veel of te weinig betrokkenheid bij de sector, te veel of te weinig open normen, of te veel of te weinig wettelijke verankering vereisen complexe afwegingen die veel vragen van het gezag en de professionaliteit van een toezichthouder. Deze meervoudige balansoefening komt in veel van de bijdragen in dit nummer tot uiting. Koelewijn schetst bijvoorbeeld in zijn artikel de gevolgen van grote trends zoals globalisering en liberalisering. Hij laat zien dat bedrijven en markten door deze ontwikkelingen in toenemende mate grensoverschrijdend te werk gaan, maar dat overheden en toezichthouders daarentegen nog vooral lokaal of nationaal ingebed zijn. Aan de hand van het trilemma van Rodrik (2013), ${ }^{1}$ dat inhoudt dat vergaande economische globalisering, lokale democratische legitimering en behoud van nationale soevereiniteit niet tegelijk naast elkaar kunnen bestaan, laat hij zien dat dit een spanning oplevert voor individuele landen die steeds minder bewegingsvrijheid hebben in het houden van toezicht. Dat levert dilemma's op met betrekking tot nationale (of lokale) handhaving in vergelijking met internationale economische mobiliteit. Deze spanning komt ook tot uiting in het eerste interview uit de Grote Toezichtinterviewestafette met René Jansen en Bernadette van Buchem, respectievelijk voorzitter en vicevoorzitter van de Kansspelautoriteit (Ksa). Het ontbreken van een Europees kader levert bijvoorbeeld meerdere uitdagingen op bij de implementatie van de

* Dr. C.H.J.M. Braun is universitair hoofddocent aan het instituut Bestuurskunde van de Universiteit Leiden en redacteur van Tijdschrift voor Toezicht.

1. D. Rodrik, 'Roepke lecture in economic geography - who needs the nation-state?', Economic Geography 2013, nr. 1, p. 1-19 (https:// drodrik.scholar.harvard.edu/publications/who-needs-nation-state).
Wet kansspelen op afstand, waarmee beoogd wordt een sterk internationale sector te legaliseren.

Deze spanning tussen lokale democratische legitimiteit en grensoverschrijdende regelgeving zien we ook terug in het artikel van De Deyne. Zij toont in haar analyse van energietoezicht(houders) in België dat de wijze van institutionele verankering van toezichthouders diverse voor- en nadelen kent als het gaat om de onafhankelijkheid van het toezicht. De institutionele inbedding van toezichthouders als uitvoerende macht, met de bijkomende politiek-bestuurlijke betrokkenheid, levert vaak een spanning op met Europese uitgangspunten van onafhankelijk toezicht. De hervorming van het energietoezicht en het formeel onderbrengen van de energietoezichthouder bij het parlement heeft de bestuurlijke onafhankelijkheid weliswaar vergroot, maar betekent nog niet dat ze daadwerkelijk politiek onafhankelijk is. De institutionele inbedding is daarmee slechts één kant van het verhaal, zoals ook uit het interview met de Ksa blijkt. Onafhankelijk toezicht is zeker ook gebaat bij een gezaghebbende toezichthouder, iets wat naast institutionele inbedding ook bepaald wordt door professionaliteit en regelmatig daadkrachtig en gezaghebbend kunnen optreden.

Het goed koers kunnen houden tussen deze complexe afwegingen vraagt soms dat een toezichthouder scherp aan de wind zeilt. Dat blijkt onder meer uit het interview met de bestuurders van de Ksa, waarbij de risicoafweging van een rechtsgang om tot meer duidelijkheid over de bevoegdheden van een toezichthouder te komen een goed voorbeeld van scherp koers kiezen is. Maar ook uit de notenkraker van De Rooij blijkt een vergelijkbaar dilemma. Hierbij staat het spanningsveld tussen nationale wetgeving en internationale verdragen centraal (in dit geval de Meststoffenwet en art. 6 EVRM). Met name de interpretatie van de wetgever is hierbij een belangrijk punt, zoals in dit geval bleek uit het toekennen van geheime marges en een specifieke interpretatie 
van de vrije bewijsleer. Het nader interpreteren van wettelijke normen en kaders vraagt dus niet alleen om oog te hebben voor de realiteit van het ondernemerschap, maar ook om een zorgvuldige afstemming met (inter)nationale wetgeving en verdragen.

Het laveren tussen streng toezicht en het ruimte bieden voor innovatie (en daarmee indirect sturen op open normen) zien we ook in de bijdrage van Canoy terug. Hierin pleit hij voor een andere manier om regels te hanteren om onbedoelde uitwassen van versoepelde regelgeving en een dominante marksector te voorkomen. Hierbij beargumenteert hij dat toezichthouders en politici moeten erkennen dat financiële instellingen (of meer algemeen het (inter)nationale bedrijfsleven), discretionaire ruimte nodig hebben om effectief te kunnen ondernemen. Explain or comply als sociaal contract tussen toezichthouder en ondernemer kan volgens hem onder bepaalde voorwaarden, waaronder bijvoorbeeld strenge regels, volledige transparantie, maar wel ruimte voor experimenteren, effectiever zijn dan de regels te veel versoepelen om tegemoet te komen aan de sector om innovatie te faciliteren.

De verschillende afwegingen die toezichthouders (en daarmee de politiek) moeten maken om onafhankelijk toezicht te realiseren zijn niet alleen individueel complex van aard, maar ook nog eens onderling verbonden. Teveel van het een leidt vaak tot te weinig van het ander: te weinig internationale kaders levert uitdagingen op in de lokale handhaving en verhouding tot de sector. Te gedetailleerde lokale of nationale invulling kan tot tegenstrijdigheden met internationale wet- en regelgeving leiden en verstikking van economische activiteit. Toch is het juist deze weerbarstigheid die het toezichtvak maken tot, zoals René Jansen en Bernadette van Buchem van de Ksa concluderen: 'een mooi maar ook uitdagend vak'. 